\title{
Examining the Effect of Joint and Dual Audits on Earnings Management Practices
}

\author{
Mohamed M. Mandour \\ Faculty of Business Administration, Beirut Arab University \\ Main Campus, Beirut, Lebanon \\ Ali M. Elharidy (Corresponding author) \\ Faculty of Business Administration, Beirut Arab University \\ Main Campus, Beirut, Lebanon \\ Tel: 961-1-300-110Ｅ-mail: a.haridy@bau.edu.lb \\ Ekramy S. Mokhtar \\ Faculty of Business Administration, Beirut Arab University \\ Main Campus, Beirut, Lebanon
}

Received: January 23, 2018

Accepted: February 2, 2018

Published: March 5, 2018

doi:10.5296/ijafr.v8i1.12526

URL: https://doi.org/10.5296/ijafr.v8i1.12526

\begin{abstract}
The purpose of the paper is to determine the impact of the voluntary adoption of the joint external audit approach in reducing earnings management practices through accruals and real operations compared with the adoption of the dual external audit approach. The research follows a quantitative approach to collect and analyze data from companies listed on the Egyptian Stock Exchange during the period 2010-2014. 104 firm-year observations are tested in the sample. The findings of the empirical study shows evidence that there are consistent earnings management practices in the studied sample regardless of the type of audit (joint or dual). There is a negative association between joint audit and discretionary accruals compared
\end{abstract}


to dual audit. This means that firms with joint audit are less engaged in accrual earnings management practices. In addition, large firms that adopt joint audit are less engaged in accrual earnings management. However, there is no effect of joint audit on real earnings management practices compared to dual audit. Our results are consistent for firm size, profitability and leverage. Both firm profitability and leverage show positive association with earnings management practices while size did not have a significant effect on either type of practice. Finally, we find that firms with high (low) profitability that adopt joint audits are less (more) likely to engage in real earnings management practices. Our results are of use to regulators, external auditors and investors.

Keywords: Joint audit, Dual audit, Accrual earnings management, Real earnings management, Egypt

\section{Introduction}

Financial reporting is intended to provide information that is relevant and a faithful representation of the events related to an economic unit. Such information should be characterized by high quality, consistency and comparability in order to increase investor confidence and support the efficiency of financial markets. However, accounting standards are highly flexible, allowing managers to manipulate profits, which adversely affects the quality and use of profits in the decision-making process.

Previous studies have provided many explanations regarding management's motives for manipulating profits. Some of these motives are related to influencing the capital market, the fulfillment of contractual conditions and/or regulatory and supervisory influence, to reduce political pressure and the impact of legislation on the company (Healy and Wahlen, 1999). Earnings may be manipulated using the accounting approach - by exploiting the flexibility afforded by generally accepted accounting principles, so-called accruals management; or by making decisions about real operations, known as earnings management through real operations. Although earnings management may benefit managers, it is detrimental to stakeholders. With the increasing accounting scandals that have plagued many major companies such as Enron and World.com, as well as the global financial crisis, criticisms have been directed to accounting and auditing as one of the main reasons for the negative impact on the credibility of published financial information. As auditor's opinion and independence became in doubt as a result of the issuance of audit reports confirming the fairness of the financial statements contrary to the truth (Sikka, 2009; Lesage et al., 2011).

On the other hand, with Arthur Anderson leaving the audit market (after the Enron scandal), attention has been directed to how to counter the risk related to concentration in the audit market resulting from the reduction of large audit firms to only four companies (BIG4). Market concentration creates an incentive to increase audit fees. Due to the lack of competition in the audit market, the possibility of one of the big 4 audit firms leaving the market for the remaining three firms could disrupt the audit market as a whole. (Lesage et al., 2011; Quick, 2012; Zerni et al., 2012; Ratzinger- Sakel et al., 2013)

As an attempt to restore public confidence in the quality of published financial statements by 
strengthening the independence of the external auditor and reducing the degree of concentration in the audit market to ensure higher audit quality, the European Commission issued the Green Paper in 2010 entitled "Audit Policy: Lessons from the Crisis". One of the mechanisms suggested is to activate the joint audit approach by using more than one external audit firm to audit the financial reports (Quick, 2012). Although the joint audit approach has already been in practice for decades; for example, Denmark has applied the joint audit approach since 1930 for listed and State-owned companies (Ratzinger-Sakel et al., 2013). The publication of the Green Paper has emerged as a new controversial mechanism, prompting researchers to examine the impact of the adoption of the joint audit approach in reducing earnings management practices. Research in this area reported conflicting results. Some studies have found a positive impact of adopting the joint audit approach in reducing earnings management (Zerni et al., 2012; Zerni et al., 2012; Bisogno and DeLuca, 2016). Other studies have concluded that there is no significant effect, or that there is a negative effect, of adopting joint audits in reducing earnings management practices (Holm and Thinggaand, 2010; Lesage et al., 2011; Ratzinger-Sakel et al., 2013; Deng et al., 2014; André et al., 2015; Velte and Azibi, 2015 ).Still, others have found that the impact of adopting the joint audit approach to reducing earnings management practices is linked to the mixture of auditor firms (Marmousez, 2008; Francis et al., 2009).

In light of the results of the previous studies and the paucity of studies on the joint audit approach in Egypt, the question is raised regarding the effect of the voluntary adoption of the joint audit approach on limiting both earnings management practices - through discretionary accrual and real operations, which is the aim of the current research in the Egyptian professional practice environment.

Therefore, the problem of this study is to answer the following research question:

- Does the voluntary adoption of the joint audit approach affect discretionary accruals and real earnings management practices compared to the dual audit approach?

To achieve the research objectives, the study is organized as follows: after the introduction in section one, section two describes the theoretical framework of earnings management. Section three reviews the concepts of joints audit and audit quality. Section four describes the dual audit approach in Egypt. Section five includes a literature review and the development of research hypotheses. Section six introduces the empirical study. Finally, section seven includes the research conclusions, recommendations and limitations.

\section{A Theoretical Framework of Earnings Management}

\subsection{The Earnings Management Concept}

Despite the abundance of studies on earnings management, there is no general agreement among researchers on a uniform definition of earnings management (Healy and Wahlen, 1999; Beneish, 2001; Yaping, 2005); Schipper (1989,P.92) defined earnings management as "the deliberate intervention in the process of preparing external financial reporting to obtain some personal gains" .Also, it was defined by Merchant and Rocknes (1994,P.81) as:" any action by management that affects profits reported in the financial statements and does not achieve 


\section{Mll Macrothink}

International Journal of Accounting and Financial Reporting ISSN 2162-3082 2018, Vol. 8, No. 1

real economic benefits and may result in long-term damage". Healy and Wahlen (1999,P.368) argue that earnings management occurs when managers use subjective judgment when preparing financial reports and structure processes to mislead certain stakeholders about the company's economic performance or to influence contractual results based on accounting figures. Finally, it was defined by Ahadiat and Hefzi (2012, P.245) as "an act of deliberate manipulation of companies' financial information with a view to achieve a certain objective".

It can be seen from the previous definitions that the decision to manage earnings is deliberately taken by management, not by mistake, and earnings are managed not only through accounting options offered by accounting standards, but also through real business decisions. The expansion in earnings management depends on the profit level targeted by management. Furthermore, earnings management has long-term damage to stakeholders. Therefore, the researchers can define earnings management as a form of manipulation of earnings intentionally performed by management, by exploiting the options offered by accounting standards and/or by making some real decisions; with a view to achieving a particular objective; which could hurt stakeholders.

\subsection{Earnings Management Motives}

Siregar and Utama (2008) argued that there are two motivations for managing profits; the first is opportunistic; when management's objective is to achieve self-benefits. The second motivation is to achieve company's efficiency; to achieve a balance between return and risk in order to ensure the survival of the company in the competition market. Healy and Wahlen (1999) pointed out that motives for managing profits can be divided into three main motives, which involve the opportunistic motive, the motivation for efficiency, and the two motivations together. This can be explained as follows:

- Market motives: The widespread use of accounting information by investors and financial analysts when evaluating stocks has created an incentive for management to manipulate earnings in an attempt to affect the share price in the short-term. This can be achieved by reducing earnings in the case of managers' desire to acquire the company at a much lower value or before issuing new stocks to the public (DuChame et al., 2004; Miloud, 2014), or to meet analysts and investors' forecasts of earnings and cash flows from operating activities; as this has a positive impact on equity prices and the value of the company (Dechow et al., 2000; Graham et al., 2005; Jordan et al., 2010; Burnett et al., 2012), or to avoid sharp fluctuations in disclosed earnings because the stock market is concerned about the extent of stability in earnings and is may take a negative reaction when earnings fluctuate (Markarian et al., 2008).

- Contractual Motives: Accounting information is used to assist in the regulation and control of contractual relationships among the company's stakeholders. According to positive accounting theory, companies' use of compensation schemes based on the earnings number may induce managers to manage earnings to maximize the present value of their remuneration. Managers in companies that do not achieve analysts' expectations are more likely to be dismissed. So, managers may use earnings management to achieve a sense of career security (Jong and Mertens, 2014). On the other hand, managers are expected to choose accounting policies that tend to increase profits with an aim to reduce the likelihood 
of violating contractual terms of debt, which are usually based on accounting figures (Watts and Zimmerman, 1990; Beneish, 2001). Also, this is aimed to achieve better exchange terms with other stakeholders such as customers, suppliers, and lenders because higher earnings enhance the company's reputation in meeting its obligations towards stakeholders (Jong and Mertens, 2014).

- Organizational motives: Organizational incentives for earnings management are present when management believes that the reported earnings have an impact on the operations of regulatory and supervisory agencies. Thus, through earnings management, management can reduce the political costs resulting from government intervention in company's affairs. According to positive theory, when a company is exposed to high political costs, managers are more likely to reduce the value of disclosed earnings. Large companies may attract the attention of the media or politicians; when they disclose huge earnings as this is seen to reflect high prices to consumers, which may be seen as an indicator of monopoly and may result in the company being subjected to antitrust scrutiny by government regulators (Watts and Zimmerman, 1990).

\subsection{Methods of Managing Earnings}

There are many methods that management can use to manage earnings. By reviewing previous studies in this area, these methods can be divided into two groups:

\subsubsection{Methods of Earnings Management through Real Operations (Real Earning Management)}

Management can influence profits by taking real decisions related to specific activities to control the timing of revenue and expenditure, some of which are related to real operational activities (Roychowdhury, 2006; Chi et al., 2011; Zang, 2012; Okolie et al. 2014):

a. Sales management: Management can influence profits by temporarily increasing sales by shifting sales for the following periods into the current period -i.e. accelerating revenue - by offering price discounts on sales, reducing the interest rate on credit sales, and/or increasing the credit period granted to customers on credit sales.

b. Management of discretionary expenses: Management can influence profits by controlling discretionary expenses such as: research and development expenses, advertising, and general and administrative expenses.

c. Management of production costs: Management can affect profits by increasing the volume of production from the volume required to meet the expected demand for products, with a view to reducing the unit fixed costs. In addition, increasing the volume of production leads to an increase in the ending inventory. This leads to a decrease in the cost of the goods sold; and vice versa if management wants to reduce profits.

Moreover, management can influence earnings per share to meet analysts' expectations by making a decision to repurchase company's shares - a real financing decision - where analysts' forecasts of earnings per share are usually used as a benchmark on the stock market. 
Companies that are able to achieve the expectations of financial analysts or report earnings per share higher than expectations; enjoy higher credibility in the stock exchange. This factor is seen as a good indicator of the company's future growth. When financial analysts' expectations are not met, the company suffers from loss of share price. This may reflect negatively on managers' incentives and reputation, leading managers to repurchase part of the capital stock in order to reduce traded shares in the market (Burnett et al., 2012; Jong and Mertens, 2014), or to postpone the timing of issuing stock options to employees to influence the number of traded shares; thus affecting the earnings per share (Okolie et al., 2014). Management can also influence profits by making real investment decisions with a view to accelerating or delaying recognition of capital gains or losses arising from the disposal of long-term assets (Kamel and Elbanna, 2009; Baatour et al., 2015).

\subsubsection{Accounting Methods of Earnings Management}

Management can influence reported earnings by exploiting the flexibility afforded by generally accepted accounting principles in selecting or changing accounting policies and estimates as well as managing accounting disclosures. The methods used to manage earnings under the accounting approach are divided into three types: (Jones, 1991; Dechowe et al., 1995; Haw et al., 2001; Shuang et al., 2010):

a. Use of accruals: The adoption of the accrual accounting system requires managers to estimate several items in the financial statements which will have a material impact on earnings; such as: the estimation of the useful life of fixed assets and their residual value at the end of their useful lives, the estimation of doubtful debts and various provisions. Management can manage earnings either by making changes to estimates previously made in past periods or by making biased estimates, which affects the reported earnings figure.

b. Changing accounting methods and policies: Management can exploit its freedom in selecting and changing the accounting policies generally accepted by GAAP, such as: selecting the method for calculating the depreciation of fixed assets, selecting the inventory pricing method, to make deliberate effects on earnings to reach a desired earnings figure.

c. Management of accounting disclosure: Management affect the real performance of the company through the re-classification of data contained in the financial statements and presented in a certain way to influence investors. For example, an operating expenses item could be reclassified into extraordinary expenses with the objective of showing operating income above its true value (McVay, 2006).

Although companies can use earnings management using accounting methods or earnings management through real operations to achieve specific profitability objectives, there are many differences between the two methods that may lead managers to prefer one method over another based on the circumstances. (Graham et al., 2005; Burnett et al., 2012; Zang, 2012; Zhu et al., 2015). These differences can be explained as follows:

First, management may switch between manipulation of real activities rather than earnings 
management using accounting methods according to the relative costs of each alternative. When the relative cost of a particular method is high, management manipulates earnings in the other way. Because companies face different costs and limitations of earnings management methods; they are expected to exhibit varying abilities to use methods. For example, earnings management through real operations is less likely to be scrutinized by an external auditor. The responsibility of the external auditor is limited to providing reasonable assurance that the financial statements are prepared in accordance with generally accepted accounting principles and that they accurately reflect the company's true activities. Auditors are not required to assess management's intentions with regards to making various real operating, investment, or financing. Managers may tend to prefer earnings management through the real operations method over accounting methods if a Big 4 audit firm was auditing the financial statements of the company.

Second, both earnings management using accounting methods and through real operations have negative effects on the company's performance, but their impact varies based on the length of time elapsed before these effects arise. Earnings management using accounting methods is accompanied by a decrease in short-term operational performance because earnings management through real operations affects the company's cash flows and is likely to result in further negative effects on the company's long-term performance. This effect may be as a result of a reduction in expenditure on $R \& D$ activities and an unnecessary increase in inventory. Earnings management through real operations is more attractive to managers who have a motivation to achieve the goal of profitability in the short term.

Third, earnings management using accounting methods is largely restricted to accounting relationships in the financial statements and may be canceled in future periods. Therefore, companies that in the past managed profits using accounting methods may switch to real manipulation activities if earnings management motives persist.

Fourth, real activities are manipulated during the fiscal year and the result is achieved by the end of the financial year, after that, managers have the opportunity to manipulate profits using accounting methods. Hence, there is a direct reciprocal relationship between the two methods; when the manipulation in real activities is larger (Smaller) than expected, managers will reduce (increase) the amount of manipulation of profits using accounting methods.

It should be noted that the use of the accounting approach to earnings management affects the reported earnings figure, while earnings management through real operations affects both cash flows and reported earnings (Roychowdhury, 2006; Burnett et al., 2012; Zang, 2012).

Despite that, earnings management might achieve some benefits for a company in the short-term it may result in damage to the company in the long-term. Therefore, many mechanisms have emerged that can contribute to reducing earnings management practices. One of such mechanisms is the adoption of the joint audit approach. In the next section, we consider the purpose of joint audit and its potential impact on audit quality.

\section{Joint Audit and Its Relationship with Audit Quality}

The concept of joint audit refers to the participation of two or more separate and independent 
audit firms in the audit process of the financial statements for a single client (Zerni et al., 2012). In a joint audit, the planning process and audit procedures and audit work are jointly organized and divided between the two auditors to ensure there is no repetition of audit duties. A joint audit results in the issuance of a single report signed by both auditors with joint collateral responsibility for the opinion issued in that report (Zerni et al., 2012).

Audit quality is known as: the probability that an auditor will discover the significant distortions or misstatements included in the financial statements and the weaknesses in the accounting system at a client's company and report on that (DeAngelo, 1981).The ability of the external auditor to discover the significant misstatements in the financial statements depends on his/her competence, while the external auditor's report on the significant misstatements in the financial statements depends on his/her independence. It is expected that the adoption of the joint audit will positively impact both the efficiency and independence of the external auditor; hence, it will positively influence the quality of the audit for the following reasons (Zerni et al., 2010; Zerni et al., 2012; Deng et al., 2014; Lobo et al., 2014; Ittonen and Trønnes, 2015; Velte and Azibi, 2015):

- It is expected that the independence of the external auditor increases under the joint audit approach compared to the individual audit approach because management's ability to influence both external auditors will be less than their ability to influence one external auditor. It is expected that the auditors will resist client's choice of less adequate accounting treatments and even threat to terminate the engagement. Also, they will be able to withstand client's pressure to express a particular opinion compared to individual audits. Under the joint audit approach, audit and consulting fees are distributed between the two audit firms, which means that there are fewer fees at risk in the case of the loss of the client. As a result, both audit firm may have a strong position against management pressures, making them able to perform the audit process more independently.

- The joint audit approach provides mutual supervision between the auditors, where each auditor will verify the appropriateness of the audit procedures of the other auditor. Each auditor will ascertain the appropriateness and sufficiency of audit evidence obtained by the other auditor. The professional opinion on the financial statements will result from on an adequate assessment of the conclusions reached based on the audit evidence obtained and the mutual supervision, which will improve audit quality by reducing the likelihood of collusion between an auditor and management.

- The audit of the financial statements by more than one auditor may avoid the possible negative impact of the changing the auditor represented in the loss of the auditor's experience and knowledge of the company's business and the industry in which it operates. This will adversely affect the efficiency and effectiveness of the audit. If an auditor is changed, the other auditor will remain. The second auditor will maintain customer knowledge, which preserve the quality of the audit.

- The joint audit approach can contribute to reducing the audit market concentration in the four large audit firms. This increases competition among audit firms, which is reflected positively in improving the level of professional performance and increasing audit quality. 
- In the joint audit approach, the expected penalties in the case of issuing an audit opinion contrary to the reality exceed the benefits expected to be obtained by each auditor individually, where the auditors share the benefits or fees between them, while the penalties will be borne by each.

- In the event of a failure of the audit, stakeholders can sue auditors for compensation for losses incurred as a result of material misstatement in the financial statements, which were not addressed in the audit report. The larger the audit firms, the greater the value of the insurance used to compensate for losses. Insurance in joint audits is typically higher compared to the case with the individual audit approach, providing an implicit guarantee to stakeholders.

On the other hand, some studies (Marmousez, 2008; Holm and Thinggaard, 2010; Zerni et al., 2010; Zerni et al., 2012; Lobo et al., 2014; Deng et al., 2014; Muraz and Ziesenib, 2014) ; Ittonen and Trønnes, 2015) argue that the adoption of the joint audit approach may adversely affect audit quality as a result of the following:

- The joint audit may suffer from a free rider problem, which may occur if an auditor tries to rely on the other auditor's effort during the audit process. Each auditor assumes that the other auditors have designed their tests to reduce the level of its substantive tests, leading to a reduction in the level of substantive tests from each auditor, which may adversely affect the accuracy of the audit evidence. Therefore, the quality of the audit will be minimized.

- The nature of the competition between audit firms and their pursue to acquire a higher market share may lead them to protect their 'know-how' and how they perform their work. It is difficult for them to cooperate closely with other auditors when conducting a joint audit, which may impair audit quality. Furthermore, accounting standards contain many accounting alternatives, which may make cooperation between auditors difficult and lead to a conflict between them in the event an auditor chooses a different accounting alternative than the other auditor would prefer. This could lead to a difficulty in reaching a common opinion among the auditors.

- The joint audit approach may harm the independence of the auditors because it opens opportunity for "Opinion Shopping" as a result of competition between auditors, which may create an incentive for them to please the client but reduce audit quality.

- The adoption of the joint audit approach may become a ceremonial process. If the same two audit firms participate in the audit of the same clients, an informal agreement may occur between them where each reviews the financial statements of a certain number of clients on their own while the other auditor only signs the report. The audit becomes, in practice, an individual audit, which may adversely affect the accuracy and quality of the audit evidence (Piot, 2007).

We conclude from the above that there is a conflict of views regarding the effect of the adoption of the joint audit approach on the quality of the audit. Supporters of the adoption of the joint audit approach believe that it has a positive impact on the quality of the audit as it results from increased auditors' independence, offering a mechanism for mutual 
cross-supervision among auditors, increasing contact and consultation between auditors, client and industry expertise to which the client belongs will not be lost if an auditor is changed, the concentration in the audit market is reduced, and the cost of issuing the audit opinion that is contrary to reality exceed the expected benefits to each auditor Individually. On the other hand, the adoption of the joint audit approach may adversely affect the quality of the audit as a result of auditor's dependence or reliance on the other auditor's effort, in addition to insufficient cooperation among auditors due to competition in the audit market, and, finally, the possibility of making the joint audit a ceremonial exercise and de facto turning it into an individual audit.

\section{Dual Audit System in Egypt}

The concept of dual audit differs from the concept of joint audit, where two or more independent auditors from separate audit firms are appointed to audit financial statements of an audit client in a way that involves: developing the audit plan separately; performing the audit work separately; no periodic cross reviews and mutual quality controls; and issuing two or more audit reports, in which every auditor is not responsible for the audit opinion expressed by the others(Ratzinger-Sakel et al., 2013). Unlike a joint audit where auditors can cross-check each other's work, no cross-checking goes on in a dual audit (Lin et al., 2014)

Lin et al. (2014) indicated that the results from the two independent audits should be consistent regarding whether the financial statements fairly represent a company's financial situation. If a major discrepancy between the two audit reports arises, the reliability of one of the reports becomes suspicious. This may negatively affect the reputation of one of the auditors. Moreover, the differences between the two audit reports may provide grounds for information users to file a lawsuit, which may also increase auditor litigation risk.

In Egypt, after the adoption of socialism and centrally planned economic policies by the Egyptian government in the early 1960s, emerged a need for an authorized governmental professional body, that audits and monitors the financial activities of public sector companies and government agencies. Accordingly, the Central Authority Organization (CAO) was enacted by a presidential decree No.129 of 1964, which was superseded by presidential decree 144 of 1988. The main duties of the CAO are (Kayed, 1990):

1. To audit state-owned companies and government agencies.

2. To supervise state-owned companies in financial and technical aspects.

3. To monitor the implementation of economic development plans.

All publicly held firms with government ownership share must audited by CAO, which acts as an external auditor by the force of low. Firms listed on the stock exchange may opt to appoint another external auditor by choice of shareholders in order to issue an audit report on their financial statements. In this case, a dual audit will be present since the two external auditors will issue separate reports on the firm's financial statements; albeit for different reasons. Where CAO's main audit responsibility is towards the state, the other (private) audit firm issues its report to the benefit of other shareholders. In addition, the nature of both audit 
reports may converge or diverge based on the findings of both auditors; one auditor may issue a clean report whereas the other auditor may issue a qualified opinion for the same firm.

\section{Literature Review and Development of Research Hypotheses}

In preparation for deriving research hypotheses, this section deals with previous literature related to the subject of the research. It reviews studies on the relationship between the adoption of the joint audit approach and earnings management practices.

Several studies (Marmousez, 2008; Francis et al., 2009; Holm and Thinggaand, 2010; Zerni et al., 2010; Lesage et al., 2011; Haapamaki et al., 2012;Zerni et al., 2012; Ratzinger-Sakel et al., 2013; Deng et al., 2014; André et al., 2015; Velte and Azibi, 2015; Bisogno and DeLuca, 2016) investigated the impact of the adoption of the joint audit approach on limiting earnings management practices. Overall, these studies reported conflicting results. Some studies found a positive effect of the adoption of the joint audit approach on reducing earnings management practices. Other studies found that there is no significant effect or negative impact on earnings management practices. Still, other studies found that the impact of the adoption of the joint audit approach on reducing earnings management practices is linked to the mix of auditors.

Haapamaki et al. (2012) found a positive impact of the adoption of the joint audit approach to reducing earnings management practices. Their study aimed to examine the impact of the adoption of voluntary joint audit on both audit quality and audit cost. The study found that companies that adopt voluntary joint audit have a high degree of conservatism and a low degree of income increase from discretionary accruals compared to companies that use individual audit by a big four audit firm; with no significant difference between the alternative combinations of auditors -two big four or one of the big four and the other non-big - on the quality of the audit. But the adoption of the joint audit approach is accompanied by an increase in the cost of the audit compared to the individual audit approach. Therefore, the study concluded that what cost companies adopting joint audits incur is justified by the higher audit quality in the form of high degree of conservatism and lower income increase due discretionary accruals.

Zerni et al. (2010) indicated that firms that adopt the joint audit approach - regardless of the nature of the audit combination - have an audit quality that is perceived by stakeholders to be greater than companies adopting the individual audit approach. Joint audit is seen by stakeholders as a control mechanism that works to prevent harming their rights. Zerni et al. (2012) aimed to test the effect of the adoption of the joint audit approach on the quality of the audit in a sample of public and private companies in Sweden. The study concluded that the companies that adopt the joint audit approach have a high degree of conservatism, low discretionary accruals, a good leverage level, and a low degree of risk of financial insolvency over the next year, compared with other companies that adopt individual audit by a big four audit firm.

Bisogno and DeLuca (2016) also found that the voluntary adoption of the joint audit approach positively affects the quality of earnings and the reliability of the financial 


\section{Mll Macrothink}

International Journal of Accounting and Financial Reporting

ISSN 2162-3082

2018, Vol. 8, No. 1

statements through its negative impact on earnings management practices for a sample of Italian companies not listed on the stock exchange.

For studies that found no significant or negative impact of adopting of joint audits in reducing earnings management practices, Holm and Thinggaand (2010) aimed to examine the effect of removing mandatory adoption of the joint audit in Denmark in 2005on both auditor fees and audit capacity to limit earnings management practices measured by discretionary accruals for a sample of 117 non-financial companies listed on the Copenhagen Stock Exchange during the period 2003-2007 including the year of removing the mandatory adoption of the joint audit (2005) and two years prior to that removal and two years after it. The study found that, with the removal of the mandatory adoption of the joint audit and companies' switch to individual audit, auditor fees decreased by approximately $25 \%$ as a result of the competition between the two audit firms to continue auditing the company and maintaining clients. Also, the study did not find difference in the ability of external audit to limit the management of earnings between the joint audit approach and the individual audit approach. Therefore, the assumption that the adoption of the joint audit approach was associated with decreased earnings management or increased audit quality compared to the individual audit approach was rejected. The study found that the reduction of audit fees due to the transition from joint to individual audit was not at the expense of audit quality measured by discretionary accruals, which is a vital indicator of earnings management and the results were insignificant.

Lesage et al. (2011) examined the effect of the adoption of the joint audit approach on audit quality, measured by discretionary accruals, for a sample of non-financial companies registered on the Danish Stock Exchange during the period (2005-2009), with a total of 372 firm-year observations. The study indicated that there is no significant relationship between the adoption of the joint audit approach and discretionary accruals. The same study was replicated for a similar sample of firms in France and Germany with the same conclusion reached.

Ratzinger-Sakel et al. (2013) indicated that, as the Green Paper suggested, although joint audit may increase competition in the audit market, particularly when the audit consists of one of the big four and the other was a non-big, the impact of the adoption of the joint audit approach on audit quality is not certain, especially if the non-big audit firm does not have the necessary resources to perform the required part of the audit process in the required quality; resulting in an imbalance in the work participation between the two audit firms, which in turn results in reducing the likelihood of achieving the expected quality of the audit despite achieving the objective of reducing concentration.

André et al. (2015) found that there is no significant effect of joint audit on audit quality, measured by working capital accrual and total accruals, for a sample of 210 French companies with mandatory joint audit, 279 English companies and 142 Italian companies, where joint audit is voluntary, during the period 2007-2011 with a total number 3155 firm-year observations.

Ittonen and Trønnes (2015) aimed to test the effect of the adoption of joint audit on audit quality - measured by the absolute value of discretionary accruals and total accruals - in a 


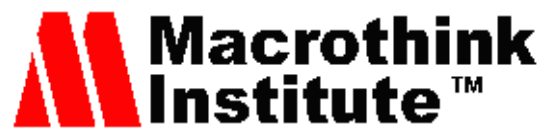

International Journal of Accounting and Financial Reporting ISSN 2162-3082

sample of Swedish and Finnish companies listed on the stock exchange. The study concluded that there is no difference in audit quality between the adoption of the joint audit approach and the adoption of the individual audit approach. Velte and Azibi (2015) also found that there was no significant effect of joint audit - two of the big four - on extraordinary working capital accruals compared to individual audit. Joint audit did not significantly "restrict" discretionary accruals for a sample of 307 French and German companies during 2008-2012. The study concluded that the adoption of the joint audit approach had no positive impact on audit quality, measured by earnings management.

A study that found that the impact of the adoption of the joint audit approach on earnings management is related to the mix of auditors is Marmousez (2008), which aimed to test the impact of the selection of audit firms under the joint audit approach on the quality of the financial statements measured by conservatism for a sample of 177 A French companies registered on the Stock Exchange in 31/12/2003. The study assumed that companies audited by two big audit firms have a higher quality of their financial statements compared to those audited by one big audit firm and another non-big audit firm or by two non-big audit firms. Contrary to what was expected, the study found that the quality of the financial statements was lower for companies audited by two of the big four audit firms compared to the rest of the companies. This result was due to the interaction between the big four firm and the other non-big firm. When the two big four auditors have the same work procedures and the same reputational risk, they are likely to rely on each other. Hence, the incentive to exert maximum effort is reduced; taking into account the fact that auditor's effort is not directly observable.

The aim of Francis et al. (2009) was to examine the impact of choosing the two audit firms in the joint audit approach on earnings quality measured by working capital accruals for a sample of 467 French companies listed on the stock market in 2003, 54 of which jointly audited by two big four, 241 audited by one big four firm and 172 companies not audited by any of the big four firms. The study found that earnings quality increased (earnings management decreased) when the company is audited by two big four firms, followed by those audited by one of the big four with a non-big firm.

Deng et al. (2014) compared the accuracy of the audit evidence under the three audit approaches; namely, individual audits by one audit firm of the big four, joint audits where both firms are big four firms, and joint audits with one big four auditor and the other is non-big. The study found no difference in the accuracy of the audit evidence between individual audits by one audit firms of the big four and joint audit by two big four firms. The study also found that when a joint audit consists of one of the big four and the other is big the audit evidence is less accurate than individual audits by one of the big four. The study justified this result by the emergence of the problem of free riders between the auditors, which negatively affect the accuracy of the audit evidence and weakens the audit quality. In addition, the joint audit approach may harm auditors' independence due to the opportunity for opinion shopping as a result of competition between auditors. This may create an incentive for them to satisfy the client to the detriment of audit quality.

By reviewing the above studies related to the joint audit approach and its impact on earnings 
management and due to the conflicting findings of these studies regarding the nature of the relationship between the adoption of joint audits and earnings management practices through discretionary accruals, the first hypothesis can be derived as follows:

H1: There is a significant relationship between the adoption of the joint audit approach and earnings management practices through discretionary accruals.

On the other hand, many studies (Zang, 2006; Zang, 2007; Chi et al., 2011; Zhu et al., 2015) found a positive impact of audit quality on real earnings management practices because the latter is less susceptible to audit where auditor's responsibility is limited to providing a reasonable assurance that financial statements are prepared in accordance with generally accepted accounting principles and that they accurately reflect the company's true activities; the auditor is not required to assess management's intentions to take decisions related to the (real) operational activities (Graham et al., 2005; Burnett et al., 2012; Zang, 2012; Zhu et al., 2015). Thus, if management is not able to manage earnings through discretionary accruals; due to external audit quality, managers may tend to use earnings management through real activities. Previous studies (Zerni et al., 2010; Haapamaki et al., 2012; Zerni et al., 2012; Bisogno and DeLuca, 2016) concluded that the adoption of joint audit increases the quality of external audit. Therefore, joint audit and the subsequent improvement in audit quality will influence earnings management practices through real activities. Therefore, the second research hypothesis can be derived as follows:

$\mathrm{H}_{2}$ : There is a significant relationship between the adoption of the joint audit approach and real earnings management practices

\section{The Empirical Study}

This section deals with the objectives of the empirical study, the identification of the study's population and sample, the sources of data, the research variables, the statistical models used to test the hypotheses. This section ends with a presentation and analysis of the results of the empirical study.

\subsection{Objectives of the Empirical Study}

The empirical study aims to test the hypotheses derived in the theoretical part of the paper regarding the effect of the voluntary adoption of the external joint audit approach, compared to the dual audit approach, on earnings management practices through discretionary accruals and through real operations, as well as to verify the impact of some control variables.

\subsection{Population and Sample}

The study's population is comprised of all the public companies whose shares are traded on the Egyptian Stock Exchange during the period 2010-2014 and belong to economic sectors that implement the voluntary joint audit approach. The sample was selected according to the following criteria:

- The company adopts the joint audit approach voluntarily during the study period.

- The company's financial year begins on 1 January and ends on 31 December each 
year.

- The company should be one traded on the stock exchange, for which trading has not been suspended temporarily or permanently during the study period.

- The availability of independent annual financial statements during the study period reported in Egyptian pounds.

- Banks and insurance companies are excluded because of their special nature that makes the calculation of their discretionary accruals different from other industries (Rusmin, 2010; Yasar, 2013). On the other hand, banks use mandatory joint audits in accordance with Article (83) of the Central Bank of Egypt Law No. (88) for the year 2003 (Ministry of Trade and Industry, 2003).

By applying the above criteria, it was found that the number of companies adopting the joint audit approach is (13) companies, divided into four economic sectors; food and beverages, construction and real estate, industrial services and products. Since the objective of the research is to determine the impact of the voluntary adoption of the joint audit approach on earnings management practices compared with the adoption of the dual audit approach, another sample of companies operating in the same four economic sectors was selected to adopt the dual audit approach, (8 companies).Thus, the total sample $=21 ; 13$ companies adopt the joint audit approach and 8 companies adopt the dual audit approach - i.e. the number of observations are 104 firm-year.

Table 1 gives information on observations according to the industry to which it belongs and the adopted audit approach.

Table 1. Sample items according to industry and adopted audit approach

\begin{tabular}{cccc}
\hline Sector & $\begin{array}{c}\text { Firms } \\
\text { adopting Joint } \\
\text { Audit }\end{array}$ & $\begin{array}{c}\text { Firms adopting } \\
\text { Dual Audit }\end{array}$ & Total Sample \\
\hline Food \& Beverages & 3 & 4 & 7 \\
\hline Construction & 5 & 2 & 7 \\
\hline Real estate & 3 & 1 & 4 \\
\hline $\begin{array}{c}\text { Industrial Services } \\
\text { and Products }\end{array}$ & 2 & 1 & 3 \\
\hline Total firms & 13 & 8 & 21 \\
\hline Total observations & 65 & 39 & 104 \\
\hline
\end{tabular}

\subsection{Data Sources}

Data on the study variables were obtained from published unconsolidated financial statements and auditors' report on these statements from the official website of the Egyptian Stock Exchange (www.egx.com.eg), the Mubasher website (www.mubasher.inf.com), Egypt For the dissemination of information, and companies' websites on the internet. Data were 


\section{$\Lambda$ Macrothink}

collected during the period 2010-2014.

\subsection{Measurement of Empirical Study Variables}

Our research seeks to test the impact of the external audit - joint or dual - on earnings management and the external audit approach adopted represents the independent variable for the study, while the method of earnings management (through discretionary accruals or real operations) is the dependent variables. The following part defines the study variables and how to measure them:

Independent variables: The independent variable is the external audit approach (audit type); a dual audit, where work is contracted with two or more independent and separate audit firms. Each firm independently carry out the audit of the financial statements of one client. Each audit firm plans the audit process, performs the procedures, audit work, and issues an audit report separately. Hence, each auditor is only held responsible for the audit opinion he/she issued (Ratzinger-Sakel et al., 2013). In a joint audit, the audit process is jointly planned and audit procedures are divided to ensure that audit functions are not duplicated and a single audit report is jointly issued with shared responsibility for the opinion there in (Zerni et al., 2012). The audit approach is measured by a dummy variable; taking the value (Zero) if the dual audit approach is adopted, and (one) in the case of adopting the joint audit approach (Zerni et al., 2010; Lesage et al., 2011; Bisogno and DeLuca, 2016).

Dependent variables: The dependent variables are the methods of earnings management represented in:

- Earnings management through discretionary accruals: we use Jones' modified model to measure discretionary (abnormal) accounting accruals (Dechow et al., 1995). Discretionary accruals are measured as follows:

a) Total Accruals (TA):

There are two alternative approaches to the calculation of total accrual: balance sheet and cash flow approaches. The cash flow approach; where total accruals is measured by difference between net income before exceptional and extraordinary items and net cash flow from operating activities, as follows:

$\mathbf{T A}_{\mathrm{it}}=\mathrm{IBX}_{\mathrm{it}}-\mathbf{O C F}_{\mathrm{it}}$

Where:

$\mathbf{T A}_{\mathbf{i t}}$ : Total accruals for company (i) at the end of year (t).

IBX $\mathbf{X}_{\mathbf{i t}}$ : Net income before exceptional and extraordinary items for company (i) at the end of year $(\mathrm{t})$.

$\mathbf{O C F}_{\text {it: }}$ Net cash flow from operating activities for company (i) at the end of year ( $t$ ).

b) Total accruals are used to estimate linear regression coefficients according to the following equation: 


$$
\mathbf{T A}_{\mathrm{it}} / \mathbf{A}_{\mathrm{it}-1}=\partial_{1}\left(\mathbf{1} / \mathbf{A}_{\mathrm{it}-1}\right)+\partial_{2}\left[\left(\Delta \mathbf{R E V}_{\mathrm{it}}-\Delta \mathbf{R E C} \mathbf{C}_{\mathrm{it}}\right) / \mathbf{A}_{\mathrm{it}-1}\right]+\partial_{3}\left(\mathbf{P P E}_{\mathrm{it}} / \mathbf{A}_{\mathrm{it}-1}\right)+\varepsilon_{\mathrm{it}}
$$

Where:

$\mathbf{T A}_{\mathbf{i t}}$ : Total accruals for company (i) at the end of year (t).

$\mathbf{A}_{\text {it-1: }}$ : Company (i)'s total assets at the end of year (t-1).

$\Delta \mathbf{R E V}_{\text {it: }}$ The change in company (i)'s revenue at the end of year (t), which represents the difference between revenue (net sales) at the end of year $(t)$ and revenue (net sales) at the end of year $(\mathrm{t}-1)$.

$\Delta \mathbf{R E C}_{\mathbf{i t}}$ : The change in company (i)'s receivables at the end of year (t), which represents the difference between net receivables at the end of year $(t)$ and net receivables at the end of year $(\mathrm{t}-1)$.

PPE $_{\mathbf{i t}}$ : Total tangible fixed assets for company (i) at end of year (t).

$\partial$ 1, $\partial$ 2, $\partial$ 3: Estimates of parameters $\alpha 1, \alpha 2, \alpha 3$, which will be used in the modified Jones model to estimate non-discretionary accruals.

вit: The random error term.

c) Estimating Non-discretionary Accruals (NDA):

Non-discretionary accruals are adjustments to the cash flows of a company, which are imposed by accounting standards; that is, the use of the accrual basis of accounting to match revenues and expenses for the period without management trying to use its own judgment to apply this basis to achieve personal benefit. NDA can be estimated as follows:

$$
\mathrm{NDA}_{i t}=\alpha_{1}\left(1 / \mathbf{A}_{\mathrm{it}-1}\right)+\alpha_{2}\left[\left(\Delta \mathrm{REV}_{\mathrm{it}}-\Delta \mathrm{REC}_{\mathrm{it}}\right) / \mathrm{A}_{\mathrm{it}-1}\right]+\alpha_{3}\left(\mathrm{PPE}_{\mathrm{it}} / \mathrm{A}_{\mathrm{it}-1}\right)
$$

Where:

NDA $A_{i t}$ : Company (i)'s estimated non-discretionary accruals at the end of year (t).

$\alpha 1, \alpha 2, \alpha 3$ : model's parameters that will be estimated.

Other variables are as previously defined.

d) Estimating Discretionary Accruals (DA):

Discretionary accruals are the adjustments to cash flows of a company made by management based on its own judgment to achieve personal benefit. This is achieved by controlling the timing of the recognition of revenues and expenses. Management also controls certain accounting estimates. Discretionary accruals can be measured by the difference between total accruals and non-discretionary accruals, as follows:

$$
\mathbf{D A}_{i t}=\mathbf{T A}_{\text {it }}-\mathbf{N D A}_{\text {it }}
$$

Discretionary accruals $\left(\mathbf{D A} \mathbf{A}_{\mathbf{i t}}\right)$ is used as a measure or earnings management; the positive 
value of discretionary accruals indicates that earnings management is in an upward direction (a deliberate increase) whereas the negative value of discretionary accruals indicates that earnings management is in a downward direction (a deliberate reduction). If discretionary accrual equals zero (or close to zero), this indicates that there is no earnings management (Radwan 2013). Since the objective of our research is to identify the existence of earnings management practices through discretionary accruals and not their direction or pattern, therefore its absolute value will be used (Rusmin, 2010; Kouaib and Jarboui, 2014; Ittonen and Trønnes, 2015).

- Real Earnings management: According to the Roychowdhury (2006), earnings management consists of real operations, i.e. from operational activities, from sales management, discretionary expenses management, and production cost management. In the absence of sufficient disclosure in published financial statements to measure discretionary expenses and production costs with an acceptable level of accuracy. Also, both sales management, discretionary expenses management, and production cost management all affect the amount of cash flows from operational activities (Roychowdhury, 2006) Therefore, we use abnormal operating cash flows (Abn-CFO) as a measure of real earnings management; following the same methodology as Matsuura (2008). Abnormal operating cash flows (Abn-CFO) will be measured by based on Roychowdhury (2006) model, as follows:

$$
\mathrm{CFO}_{\mathrm{it}} / \mathbf{A}_{\mathrm{it}-1}=\alpha_{1}\left(1 / \mathbf{A}_{\mathrm{it}-1}\right)+\alpha_{2}\left(\operatorname{Sales}_{\mathrm{it}} / \mathbf{A}_{\mathrm{it}-1}\right)+\alpha_{3}\left(\Delta \mathrm{Sales}_{\mathrm{it}} / \mathbf{A}_{\mathrm{it}-1}\right)+\varepsilon_{\mathrm{it}}
$$

Where (CFO) reflects operating cash flows and the other variables as defined previously.

From the previous equation, the parameters $\alpha 1, \alpha 2, \alpha 3$ will be used to estimate the normal or expected operating cash flows of each company. The difference between the actual operating cash flows of the company and the normal (calculated) operating cash flows represent the abnormal (or managed) operating cash flows (Abn-CFO). The absolute value of abnormal operating cash flows will also be used as the objective of the research is to identify the existence of earnings management practices through real operations but not its direction or pattern (Rusima, 2010; Kouaib and Jarboui, 2014).

\section{Control variables:}

Firm size: Previous studies (Gerayli et al., 2011; Memiş and Çetenak, 2012; Zang, 2012; Curuk and Yassr, 2014) indicate that firm size negatively affects earnings management practices, which means that large companies are less likely to manage earnings because they are more scrutinized by financial analysts and investors. Firm size is measured as the natural logarithm of total assets (Memiş and Çetenak, 2012; Zang, 2012; Yaşar, 2013).

Leverage: leverage is used to control for financial risk. Results of previous studies (Gerayli et al., 2011; Kouaib and Jarboui, 2014; Rutledge et al., 2014) indicate that the higher the leverage, the higher the incentive to manage profits upwards in order to avoid a breach of debt agreements. Financial leverage is measured by dividing total liabilities over total assets (Gerayli et al., 2011; Memis and Centenak, 2012; Zang, 2012; Yaşar, 2013; Rutledge et al., 2014)). 


\section{Mll Macrothink}

International Journal of Accounting and Financial Reporting

ISSN 2162-3082 2018, Vol. 8, No. 1

Return on Assets (ROA): ROA is used to control for a company's financial performance. Previous studies (Rusmin, 2010; Zhu et al., 2015) show an inverse relationship between ROA and earnings management practices. We measure ROA by dividing net profit over total assets (Rusmin, 2010; Zhu et al., 2015).

Interassetsaudit: The interaction between firm size and joint audit.

\subsection{Statistical Models Used to Test Research Hypotheses}

To test the research hypotheses, multiple linear regression analysis was used by modeling two linear regression analysis as follows:

6.5.1 A Model to Test the Effect of the Joint Audit Approach on Earnings Management through Discretionary Accruals

To test the impact of the adoption of the joint audit approach on earnings management through discretionary accruals compared to the dual audit approach (the first research hypothesis), the following multiple linear regression model is formulated:

$$
\begin{array}{r}
\left|\mathrm{DA}_{\mathrm{it}}\right|=\beta_{0}+\beta_{1} \text { Audit Type }_{\text {it }}+\beta_{2} \text { FirmSize }_{\text {it }}+\beta_{3} \text { Leverage }_{\text {it }}+\beta_{4} \text { ROA }_{\text {it }}+ \\
\beta_{5} \text { Interassetsaudit } \\
\text { it }
\end{array}
$$

Where:

|DA $\mathbf{A}_{\text {it }} \mid$ : The absolute value of company (i)'s discretionary accruals for year (t), as an indicator of earnings management through discretionary accruals.

B0: Regression constant.

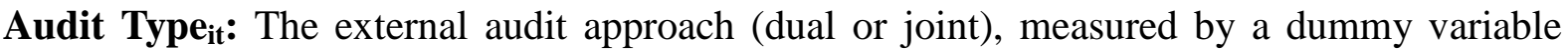
which equals one if a company adopts the joint audit approach, and zero if it adopts the dual audit approach.

Firm Size it: Company (i)'s size for year (t), measured by total assets.

Leverage $_{\text {it: }}$ Company (i)'s financial leverage in year ( $\mathrm{t}$ ), measured by the ratio of total debt to total assets.

ROA $_{i t}$ : The rate of return on assets for company (i) for year (t), measured by net profit over total assets.

Interassetsaudit ${ }_{i t}$ : The interaction between firm size and joint audit.

$\varepsilon_{\text {it: }}$ The random error term.

6.5.2 A Model to Test the Impact of the Joint Audit Approach on Earnings Management through Real Operations

To examine the impact of the adoption of the joint audit approach on earnings management through real activities compared to the dual audit approach (the second research hypothesis), the following multiple regression model is formulated: 
$\mid$ Abn-CFO $_{\text {it }} \mid=\beta_{0}+\beta_{1}$ Audit Type $_{\text {it }}+\beta_{2}$ FirmSize $_{\text {it }}+\beta_{3}$ Leverage $_{\text {it }}+\beta_{4}$ ROA $_{\text {it }}+$ $\beta_{5}$ Interassetsaudit ${ }_{\text {it }}+\varepsilon_{\text {it }}$

Where:

|Abn-CFO ${ }_{\text {it }}$ : The absolute value of company (i)'s abnormal cash flows from operating activities for year $(t)$, as an indicator of earnings management through real operations.

Other variables are as defined in the previous model.

\subsection{Statistical Analysis Results}

Descriptive statistics

Table 2 provides descriptive statistics about the dependent (earnings management) and independent and controls variables (audit type, firm size, profitability and leverage). Regarding earnings management, the mean discretionary accrual is 0.0729 with a minimum 0 and a maximum 0.53 while the average absolute value of abnormal cash flows from operating activities is 0.0745 with a minimum 0 and a maximum 0.33. It seems that the average of both variables is close to each other. Regarding control variables, profitability has a mean of $6.76 \%$ while the minimum and maximum are- $0.08 \%$ and $33 \%$ respectively. The average firm size is 4371,102,716 pounds and the minimum and maximum are 57,181,273 and $57,234,322,349$ pounds respectively. In addition, regarding audit type 65 (62.5\%) firm has joint audit and 39 (37.5\%) firm has dual audit (Table 3).

Table 2. Descriptive Statistics

\begin{tabular}{|c|c|c|c|c|c|}
\hline & $\mathrm{N}$ & Minimum & Maximum & Mean & Std. Deviation \\
\hline |DA & 104 & .00 & .53 & .0729 & .07930 \\
\hline |Abn-CFO| & 104 & .00 & .33 & .0745 & .07885 \\
\hline Assets & 104 & $57,181,273$ & $57,234,322,349$ & $4,371,102,716$ & $11,837,336,628$ \\
\hline ROA & 104 & -.08 & .33 & .0676 & .08188 \\
\hline Leverage & 104 & .09 & .96 & .4652 & .18548 \\
\hline Valid N (listwise) & 104 & & & & \\
\hline
\end{tabular}

Table 3. Audit Type

\begin{tabular}{rrrrrr}
\hline & & Frequency & Percent & Valid Percent & $\begin{array}{c}\text { Cumulative } \\
\text { Percent }\end{array}$ \\
\hline \multirow{3}{*}{ Valid } & Joint & 65 & 62.5 & 62.5 & 62.5 \\
& Dual & 39 & 37.5 & 37.5 & 100.0 \\
& Total & 104 & 100.0 & 100.0 & \\
\hline
\end{tabular}




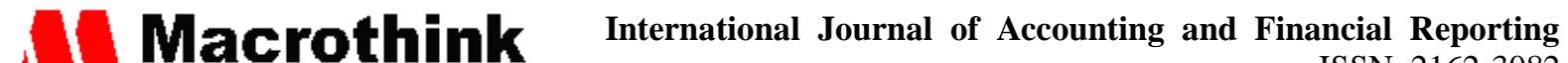 ISSN 2162-3082 2018, Vol. 8, No. 1}

\section{Results of regression analysis}

The regression analysis result -Table 4- indicates that the model is significant in testing the association between the absolute discretionary accrual as a proxy for earning management practices and the independent variables $(\mathrm{F}=2.45, \mathrm{p}<0.05)$.

Regression analysis result indicates a significant negative association between discretionary accrual and joint audit ( $\mathrm{p}<0.10)$, So (H1) is accepted. Joint audit has significant influence on earning management practices through discretionary accruals compared to dual audit. This means that external auditors in joint audit exercise high levels of due care and professional skepticism compared to the case of dual audit. This result is consistent with that of Zerni et al. (2010),Haapamaki et al. (2012) and Bisogno and DeLuca (2016). This result can be justified for several reasons. For example, the independence of the external auditor is expected to be higher in the joint audit compared to dual audit since management's ability to influence two external auditors working together will be limited. Therefore, the auditors' ability - in joint audit - will be higher to resist client's choice of less adequate accounting treatments. In addition, they will be able to withstand client's pressure to express a particular opinion compared to dual audit. Under the joint audit approach, the dependency on audit fees will be decreased since the fees will be distributed between two audit firms. As a result, both audit firm stand strongly against management pressures, which in turn enable to perform the audit process more independently. Moreover, joint audit facilitates mutual supervision between auditors, since each auditor will verify the appropriateness of the audit procedures of the other auditor and audit procedures/audit judgments are expected to be of higher quality under the joint audit compared to the dual audit. Auditors under the joint audit approach benefit from the opportunity to communicate with and consult each partner with sufficient experience and knowledge about the client.

The interaction between firm size and joint audit provides more insight about the impact of joint audit on earning management practices through discretionary accruals. The regression analysis result shows a significant negative association between discretionary accrual and the interaction between firm size and joint audit $(\mathrm{p}<0.05)$. This result conform the above-mentioned results. Large firms that audit through joint audit are less engaged in earning management practices through discretionary accruals. It seems that auditors in joint audit exercise more effort when they audit large firms. This may happen because large firms receive more public visibility and receive more pressure form the society coupled with auditors desire to protect their professional reputation that lead to less earning management practices.

Table 4. The result of regression analysis related to discretionary accrual

\begin{tabular}{llllll}
\multicolumn{6}{c}{ Model Summary } \\
\hline Model & $\mathrm{R}$ & R Square & $\begin{array}{c}\text { Adjusted R } \\
\text { Square }\end{array}$ & $\begin{array}{c}\text { Std. Error of the } \\
\text { Estimate }\end{array}$ & Durbin-Watson \\
\hline $.336^{\mathrm{a}}$ & .113 & .068 & .07658 & 1.332 \\
\hline
\end{tabular}

a. Predictors: (Constant), interassetsaudit, ROA, Audit type, Leverage, Assets

b. Dependent Variable: $|\mathrm{DA}|$ 


\begin{tabular}{lccccc}
\multicolumn{6}{c}{ ANOVA $^{\mathbf{a}}$} \\
\hline Model & Sum of Squares & df & Mean Square & F & Sig. \\
\hline Regression & .073 & 5 & .015 & 2.493 & $.036^{\mathrm{b}}$ \\
Residual & .575 & 98 & .006 & & \\
Total & .648 & 103 & & & \\
\hline
\end{tabular}

a. Dependent Variable: ABSAccrual

b. Predictors: (Constant), interassetsaudit, ROA, Audit type, Leverage, Assets

Coefficients

\begin{tabular}{|c|c|c|c|c|c|c|c|}
\hline \multirow[t]{2}{*}{ Model } & \multicolumn{2}{|c|}{ Unstandardized Coefficients } & \multirow{2}{*}{$\begin{array}{c}\text { Standardized } \\
\text { Coefficients } \\
\text { Beta }\end{array}$} & \multirow[t]{2}{*}{$\mathrm{t}$} & \multirow[t]{2}{*}{ Sig. } & \multicolumn{2}{|c|}{$\begin{array}{c}\text { Collinearity } \\
\text { Statistics }\end{array}$} \\
\hline & $\mathrm{B}$ & Std. Error & & & & Tolerance & VIF \\
\hline (Constant) & $.056 \quad .036$ & & 1.539 & & .127 & & \\
\hline Audit type & $\begin{array}{ll}-.029 & .017\end{array}$ & -.179 & -1.710 & & .090 & .826 & 1.210 \\
\hline Assets & $8.878 \mathrm{E}-014 \quad .000$ & .013 & .103 & & 918 & .548 & 1.824 \\
\hline ROA & $.238 \quad .112$ & 246 & 2.125 & & 036 & 676 & 1.480 \\
\hline Leverage & .048. & .255 & 2.272 & & .025 & .718 & 1.393 \\
\hline interassetsaudit & $\begin{array}{ll}-.056 & .027\end{array}$ & -.272 & -2.069 & & .041 & .523 & 1.911 \\
\hline
\end{tabular}

a. Dependent Variable: |DA|

Regression analysis result - Table 5 - indicates a non-significant association between real earning management and joint audit $(\mathrm{p}>0.10)$. So, $(\mathrm{H} 2)$ is rejected. Joint audit has no significant influence on real earning management practices compared to dual audit. This result consistent with the results of Lesage et al. (2011), André et al. (2015), Ittonen and Trønnes (2015), Velte, and Azibi (2015).

Several studies find non-significant impact of joint audit on real earnings management compared to individual audit approach (see for example Holm and Thinggaand, 2010). This could be explained as follows: Ratzinger-Sakel et al. (2013) argue that in joint audit imbalance in filed work may be exist in joint audit as result of the lacking of resources available to non-big audit firm and this impairs the possibility of having high audit quality in terms of reducing earnings management practices. In addition, emerging of a new agency problem between auditors in joint audit may cause a threat to audit quality in decrease auditors' ability to limit earnings management practices by their clients (Marmousez, 2008). In the same vein, Deng et al. (2014) argue that in joint audit there is a high potential to the emergence of free riders problem and opinion shopping where the auditors may tend to satisfy their clients even at the expense of audit quality and audit evidence effectiveness. 
Table 5. The result of regression analysis related to real earning management

Model Summary

\begin{tabular}{ccccc}
\hline Model & R & R Square & $\begin{array}{c}\text { Adjusted R } \\
\text { Square }\end{array}$ & $\begin{array}{c}\text { Std. Error of the } \\
\text { Estimate }\end{array}$ \\
\hline $.539^{\mathrm{a}}$ & .290 & .254 & .06809 \\
\hline
\end{tabular}

a. Predictors: (Constant), interassetsaudit, ROA, Auditfirm, Leverage, Assets

\begin{tabular}{lccccc}
\multicolumn{6}{c}{ ANOVA $^{\mathrm{a}}$} \\
\hline Model & Sum of Squares & df & Mean Square & F & Sig. \\
\hline Regression & .186 & 5 & .037 & 8.021 & $.000^{\mathrm{b}}$ \\
Residual & .454 & 98 & .005 & & \\
Total & .640 & 103 & & & \\
\hline
\end{tabular}

a. Dependent Variable: |Abn-CFO|

b. Predictors: (Constant), interassetsaudit, ROA, Auditfirm, Leverage, Assets

Coefficients

\begin{tabular}{|c|c|c|c|c|c|c|c|}
\hline \multirow[t]{2}{*}{ Model } & \multicolumn{2}{|c|}{$\begin{array}{l}\text { Unstandardized } \\
\text { Coefficients }\end{array}$} & \multirow{2}{*}{$\begin{array}{c}\text { Standardized } \\
\text { Coefficients } \\
\text { Beta }\end{array}$} & \multirow[t]{2}{*}{$\mathrm{t}$} & \multirow[t]{2}{*}{ Sig. } & \multicolumn{2}{|c|}{$\begin{array}{l}\text { Collinearity } \\
\text { Statistics }\end{array}$} \\
\hline & B & $\begin{array}{l}\text { Std. } \\
\text { Error }\end{array}$ & & & & Tolerance & VIF \\
\hline (Constant) & .021 & .032 & & .638 & .525 & & \\
\hline Auditfirm & -.012 & .015 & -.072 & -.766 & .446 & .826 & 1.210 \\
\hline Assets & $-9.409 \mathrm{E}-013$ & .000 & -.141 & -1.229 & .222 & .548 & 1.824 \\
\hline ROA & .559 & .100 & .581 & 5.610 & .000 & .676 & 1.480 \\
\hline Leverage & .070 & .043 & .164 & 1.630 & .106 & .718 & 1.393 \\
\hline interassetsaudit & .021 & .024 & .103 & .873 & .385 & .523 & 1.911 \\
\hline
\end{tabular}

a. Dependent Variable: |Abn-CFO|

Since the result in Table 6 documents a significant association between profitability (ROA) and real earning management, the interaction between profitability (ROA) and joint audit (interprofitaudit) may provide more insight about the impact of joint audit on real earning management practices. The regression analysis result -Table 7- shows a significant negative association between real earnings management practices and the interaction between profitability and joint audit $(\mathrm{p}<0.05)$. This result indicates that firms with high profitability and adopt joint audit are less engaged in real earning management practices. It seems that auditors in joint audit exercise more effort when they audit high profitable firms. This may take place because high profitable firms have more public visibility, thus, are subject to public pressure form the society supported by auditors desire to sustain their professional reputation and this result in less earning management practices. 


\section{MInstitute ${ }^{\text {Mink }}$}

International Journal of Accounting and Financial Reporting

ISSN 2162-3082

Table 6. The result of regression analysis related to real earning management with interaction variable

\begin{tabular}{llrrrr}
\multicolumn{6}{c}{ Model Summary } \\
\hline Model & R & R Square & $\begin{array}{c}\text { Adjusted R } \\
\text { Square }\end{array}$ & $\begin{array}{c}\text { Std. Error of the } \\
\text { Estimate }\end{array}$ & Durbin-Watson \\
\hline & $.559^{\mathrm{a}}$ & .313 & .278 & .06702 & 1.677 \\
\hline
\end{tabular}

a. Predictors: (Constant), interprofitaudit, Assets, Audit type, Leverage, ROA

b. Dependent Variable: $\mid$ Abn-CFO|

\begin{tabular}{llrrrrr}
\multicolumn{7}{c}{ ANOVA $^{\mathrm{a}}$} \\
Model & & Sum of Squares & df & Mean Square & F & \multicolumn{1}{c}{ Sig. } \\
\hline & Regression & .200 & 5 & .040 & 8.913 & $.000^{\mathrm{b}}$ \\
& Residual & .440 & 98 & .004 & & \\
Total & .640 & 103 & & & \\
\hline
\end{tabular}

a. Dependent Variable: |Abn-CFO|

b. Predictors: (Constant), interprofitaudit, Assets, Audit type, Leverage, ROA

\begin{tabular}{|c|c|c|c|c|c|c|c|}
\hline \multicolumn{8}{|c|}{ Coefficients } \\
\hline \multirow[t]{2}{*}{ Model } & \multicolumn{2}{|c|}{$\begin{array}{c}\text { Unstandardized } \\
\text { Coefficients }\end{array}$} & \multirow{2}{*}{$\begin{array}{c}\text { Standardized } \\
\text { Coefficients } \\
\text { Beta }\end{array}$} & \multirow[t]{2}{*}{$\mathrm{t}$} & \multirow[t]{2}{*}{ Sig. } & \multicolumn{2}{|c|}{$\begin{array}{c}\text { Collinearity } \\
\text { Statistics }\end{array}$} \\
\hline & $\mathrm{B}$ & Std. Error & & & & Tolerance & VIF \\
\hline (Constant) & .024 & .032 & & .768 & .445 & & \\
\hline Audit type & -.017 & .015 & -.104 & -1.134 & .260 & .826 & 1.210 \\
\hline Assets & $-6.364 \mathrm{E}-013$ & .000 & -.096 & -1.104 & .272 & .936 & 1.069 \\
\hline ROA & .792 & .142 & .823 & 5.563 & .000 & .321 & 3.119 \\
\hline Leverage & .086 & .041 & .203 & 2.102 & .038 & .753 & 1.328 \\
\hline interprofitaudit & -.042 & .021 & -.266 & -1.987 & .050 & .391 & 2.554 \\
\hline
\end{tabular}

a. Dependent Variable: $|\mathrm{Abn}-\mathrm{CFO}|$

The result of the accrual model indicates a significant positive association between profitability, leverage and earning management ( $\mathrm{p}<0.01,0.05$, respectively). Companies that are more profitable tend to practice more real and accrual earnings management to reduce intervention from regulatory authorities and aim to support their image and legitimacy. In addition, high leverage companies may face more pressure from capital provider and therefore practice more earnings management to meet debt covenants sine breaching debt covenants may harm the firm reputation.

\section{Conclusions}

This study aims to examine the effect of joint audit on accrual and real earnings management practices compared with dual audit. The results of the empirical analysis show a significant 
negative effect of the joint audit approach on earnings management through discretionary accruals compared to the dual audit approach. Therefore, the first research hypothesis of the study was accepted. Also, our results show non-significant effect of the adoption of the joint audit approach on earnings management practices through real operations compared with the adoption of the dual audit approach. It seems that large firms adopting the joint audit approach exercise less accrual earnings management practices. In addition, profitable firms adopting the joint audit approach are less engaged in real earnings management practices.

The importance of this research is attributed to a number of considerations, which can be presented as follows:

The research into the debate on the effectiveness of the joint audit approach contributes to reducing earnings management practices and improving the quality of earnings by identifying a practical guide - based on actual data of a sample of listed companies - of the impact of the joint audit approach on earnings management practices. This will help regulators to consider the necessity of adopting the joint audit approach to include all Egyptian business sectors.

Previous studies have dealt with the relationship between the adoption of the joint audit approach and one of the methods of earnings management -earnings management through accruals - although managers are likely to use multiple methods of earnings management at the same time (Zang, 2012; Zhu et al., 2015). Thus, there is no study - within the limits of the researchers' knowledge - that focused on examining the impact of the adoption of the joint audit approach on the method of managing earnings through discretionary accruals and through real operations together - especially in the Egyptian environment -which will enable us to understand the full effect of adopting the joint audit approach on earnings management methods, which is what the current research contributes to.

Previous studies (Cohen et al., 2008; Jordan et al., 2010; Memiş and Çetenak, 2012; Rutledge et al., 2014; Enomoto et al., 2015) took a launching platform that in a legal environment where investors' rights are protected, such as the Sarbanes Oxley Act (SOX); where the quality of external audit will adversely affect earnings management using discretionary accruals due to the litigation risk that audit firms will face in the event of failure to detect earnings management practices. This leads us to question how far does this result exist in the Egyptian audit environment, which does not adequately protect the rights of stakeholders (Anis, 2014).

A research gap in the accounting literature can be identified in relation to the effects of the adoption of the joint audit approach in developed countries and the scarcity of studies that dealt with that impact in the developing countries, which led to a lack of adequate understanding of the effects of this adoption in developing countries. It is expected that these relationships will be different in developed countries compared to less developed countries (Jordan et al., 2010; Yaşar, 2013).

Based on our findings, several recommendations to policy makers can be suggested. First, the audit profession in Egypt should issue an audit standard that addresses the responsibilities of auditors conducting the joint audit, as well as developing guidelines to ensure an appropriate 


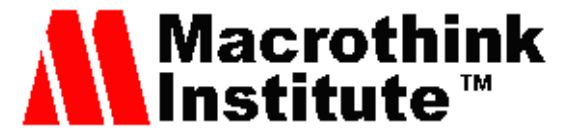

International Journal of Accounting and Financial Reporting ISSN 2162-3082 2018, Vol. 8, No. 1

level of cooperation between auditors to achieve the target quality of the audit. This situation is also important since the joint audit approach is a mandatory requirement in Egypt for banks, investment funds and other financial institutions. Second, there is a need to control the process of conducting joint audits prescribed by current laws by relevant regulatory bodies; such as the Financial Control Authority (FCA). Third, adopting stiffer penalties in the case of collision between auditors in the joint audit may prevent the joint audit from being a merely ceremonial process or as an individual audit process. Fourth, auditors in a joint audit must cooperate and exchange information to ensure that the audit process is of the desired quality. Fifth, there is a need to adopt laws that protect the rights of investors and other stakeholders and harsher penalties in the case of issuing false audit opinions.

The study does not examine the manipulation of earnings by changing the classification of items in the income statement. The study does not examine the management of operational cash flows - as an indicator of real earnings management - by manipulating the classification of certain items within the cash flow statement sections because this does not affect the net profit figure (Lee, 2012). The study is limited to studying earnings management through real operations other than investment and financing activities. The study sample is limited to companies registered in the Egyptian Stock Exchange during the period from 2010 until 2014. Finally, the possibility of generalizing the results of the research will be conditional on the selection criteria of the population and sample of the study.

\section{References}

Ahadiat, N., \& Hefzi, H. (2012). An Investigation of Earnings Management Practices: Examining Generally Accepted Accounting Principles. International Journal of Business and Social Science, 3(14), 245-251.

André, P., Broye, G., Christopher Pong, C., \& Schatt, A. (2015). Are Joint Audits Associated with Higher Audit Fees?. European Accounting Review. https://doi.org/ 10.1080/09638180.2014.998016

Anis, A. (2014). Auditors' perception of audit firm rotation impact on audit quality in Egypt. Accounting and Taxation, 6(1), 105-120.

Baatour, K., Ben Othman, H., \& Hussainey, K. (2015).The effect of multiple directorships on real and accrual-based earning management: Evidence from Saudi listed firms. Cairo University International Conference on Accounting - CUICA.

Beneish, M. D. (2001). Earnings Management: A Perspective. Managerial Finance, 27(12), 3-17. https://doi.org/10.1108/03074350110767411

Bisogno, M., \& DeLuca, R. (2016). Voluntary joint audit and earnings quality: Evidence from Italian SMEs. International Journal of Business Research and Development, 5(1), 1-22. https://doi.org/10.24102/ijbrd.v5i1.594

Burnett, B. M., Cripe, B. M., Martin, G .W., \& Mc-Allister, B. P. (2012). Audit quality and the trade-off between accretive stock repurchases and accrual-based earnings management. The Accounting Review, 87(6), 1861-1884. https://doi.org/10.2308/accr-50230 


\section{$\triangle$ Macrothink}

International Journal of Accounting and Financial Reporting ISSN 2162-3082

Chi, W., Lisic, L.L., \& Pevzner, M. (2011). Is enhanced audit quality associated with greater real earnings management?. Accounting Horizons, 25(2), 315-335. https://doi.org/10.2308/acch-10025

Cohen, D. A., Dey, A., \& Lys, T. Z. (2008). Real and accrual-based earning management in the pre-and post-Sarbanes-Oxley periods. The Accounting Review, 83(3), 757-786. https://doi.org/10.2308/accr.2008.83.3.757

Cohen, D. A., \& Zarowin, P. (2010). Accrual-based and real earnings management activities around seasoned equity offerings. Journal of Accounting and Economics, 50(1), 2-19. https://doi.org/10.1016/j.jacceco.2010.01.002

Curuk, T., \& Yasar, A. (2014). The association between earnings management and auditor reporting: Evidence from Turkish stock market. International Journal of Academic Research, 6(3), 53-64. https://doi.org/10.7813/2075-4124.2014/6-3/B.9

DeAngelo, L. E. (1981). Auditor size and audit quality. Journal of accounting and Economics, 3(3), 183-199. https://doi.org/10.1016/0165-4101(81)90002-1

Dechow, P. M., Salon, R. G., \& Sweeney, A. P. (1995). Detecting earning management. The Accounting Review, 70(2), 193-225.

Dechow, P. M., Richardson, S. A., \& Tuna, A. I. (2000). Are benchmark beaters doing anything wrong?. https://doi.org/10.2139/ssrn.222552

Deng, M., LU, T., Simunic, D. A., \& Ye, M. (2014). Do Joint audits improve or impair audit quality?. Journal of Accounting Research, 52(5), 1029-1060. https://doi.org/10.1111/1475-679X.12060

Enomoto, M., Kimura, F., \& Yamaguchi, T. (2015). Accrual-based and real earnings management: An international comparison for investor protection. Journal of Contemporary Accounting \& Economics, 11, 183-198. https://doi.org/10.1016/j.jcae.2015.07.001

Francis, J. R., Richard, C., \& Vanstraelen, A. (2009). Assessing France's joint audit requirement: Are two heads better than one. Auditing: A Journal of Practice \& Theory, 28(2), 35-63. https://doi.org/10.2308/aud.2009.28.2.35

Gerayli, M. S., Yanesari, A. M., \& Ma'atoofi, A. R. (2011). Impact of audit quality on earnings management: Evidence from Iran. International Research Journal of Finance and Economics, 66, 77-84.

Graham, J. R., Harvey, C. R., \& Rajgopal, S. (2005). The economic implication of corporate financial reporting. Journal of Accounting and Economics, 40(1-3), 3-73. https://doi.org/10.1016/j.jacceco.2005.01.002

Habib, A., Jiang, H., \& Zhou, D. (2014). Audit quality and the market pricing of earnings and earnings components in China. Asian Review of Accounting, 22(1), 20-34. https://doi.org/10.1108/ARA-05-2013-0034

Haw, I., Qib, D., \& Wu, W. (2001). The nature of information in accruals and cash flows in an 
emerging capital market: The case of China. The International Journal of Accounting, 36, 391-406. https://doi.org/10.1016/S0020-7063(01)00107-8

Healy, P. M., \& Wahlen, J. M.(1999). A review of earnings management literature and its implication for standard setting. Accounting Horizons, 13(4), 365-383. https://doi.org/10.2308/acch.1999.13.4.365

Holm, C., \& Thinggaard, F. (2010). Joint audits - benefit or burden?. Retrieved May 15, 2016, from https://papers.ssrn.com/sol3/papers.cfm?abstract_id=1702867

Ittonen, K., \& Trønnes, P. (2015). Benefits and costs of appointing joint audit engagement partners. Auditing: A Journal of Practice \& Theory, 34(3), 23-46. https://doi.org/10.2308/ajpt-50934

Jones, J. J. (1991). Earnings management during import relief investigations. Journal of Accounting Research, 29(2), 193-228. https://doi.org/10.2307/2491047

Jong, A., \& Mertens, G. (2014). How does earnings management influence investor's perceptions of firm value? Survey evidence from financial analysts. Review of Accounting Studies, 19(2), 606-627.

Jordan, C. E., Clark, S. J., \& Hames, C. C. (2010). The impact of audit quality on earnings management to achieve user reference points in EPS. Journal of Applied Business Research, 26(1), 19-30. https://doi.org/10.19030/jabr.v26i1.273

Kamel, H., \& Elbanna, S. (2009). Assessing the perception of the quality of reported earnings in Egypt. Managerial Auditing Journal, 25(1), 32-52. https://doi.org/10.1108/02686901011007298

Kayed, M. A. E. (1990). Accounting Regulation in Egypt in relation to Western Influence. Unpublished $\mathrm{PhD}$, University of Hull.

Kouaib, A., \& Jarboui, A. (2014). External audit quality and ownership structure interaction and impact on earnings management of industrial and commercial Tunisian sectors. Journal of Economics, Finance and Administrative Science, 19, 78-89. https://doi.org/10.1016/j.jefas.2014.10.001

Lee, L. F. (2012). Incentives to inflate reported cash from operations using classification and timing. The Accounting Review, 87(1), 1-33. https://doi.org/10.2308/accr-10156

Lesage, C., Ratzinger-Sakel, N., \& Kettunen, J. (2011). Is joint audit bad or good? Efficiency perspective evidence from three European countries. https://doi.org/10.2139/ssrn.1982732

Lin, C., Lin, H., \& Yen, A. (2014). Dual audit, audit firm independence, and auditor conservatism. Review of Accounting and Finance, 13(1), 65-87. https://doi.org/10.1108/RAF-06-2012-0053

Lobo, G., Paugam, L., Zhang, L., \& Casta, J. (2014). Effect of joint auditor pair composition on conservatism: Evidence from impairment tests. Retrieved April 8, 2017, from https://halshs.archives-ouvertes.fr/hal-00993007/document 
Markarian, G., Pozza, L., \& Prencipe, A. (2008). Capitalization of R\&D costs and earnings management: Evidence from Italian listed companies. The International Journal of Accounting, 43, 246-267. https://doi.org/10.1016/j.intacc.2008.06.002

Marmousez, S. (2008). The choice of joint-auditors and earnings quality: Evidence from French listed companies. CAAA Annual Conference Paper. https://doi.org/10.2139/ssrn.1330061

Matsuura, S. (2008). On the relation between real earnings management and accounting earnings management: Income smoothing perspective. Journal of International Business Research, 7(3), 63-77.

McVay, S. (2006). Earnings Management using classification shifting: An examination of core earnings and special items. The Accounting Review, 81(3), 501-531. https://doi.org/10.2308/accr.2006.81.3.501

Memiş, M. Ü., \& Çetenak, E. H. (2012). Earnings management, audit quality and legal environment: An international comparison. International Journal of Economics and Financial Issues, 2(4), 460-469.

Merchant, K., \& Rockness, J. (1994). The ethics of managing earning: An empirical investigation. Journal of Accounting and Public Policy, 13, 79-94. https://doi.org/10.1016/0278-4254(94)90013-2

Miloud, T. (2014). Earnings management and initial public offerings: An empirical analysis. The Journal of Applied Business Research, 30(1), 117-134. https://doi.org/10.19030/jabr.v30i1.8288

Ministry of Trade and Industry. (2003). Law No. 88 - The Central Bank, Banking System and Currency. Retrieved April 1, 2017, from http://www.mfti.gov.eg

Mohamed, D. M., \& Habib, M. H. (2013). Auditor independence, audit quality and the manadatory auditor rotation in Egypt. Education, Business and Society Contemporary Middle Eastern Issues, 6(2), 116-144. https://doi.org/10.1108/EBS-07-2012-0035

Muraz, M., \& Ziesenib, R. (2014). How do reputation and liability regimes affect audit quality in a joint audit setting. German Economic Association of Business Administration. Retrieved from http://geaba.de/DP/DP-14_23.pdf

Okolie, A. O., Izedonmi, F. O., \& Enofe, A. O. (2014). Audit Quality and Cash - Based Earnings Management of Quoted Companies in Nigeria. Journal of Finance and Investment Analysis, 3(1), 35-50.

Piot, C. (2007). Auditor concentration in a joint-auditing environment: The French market 1997-2003. Managerial Auditing Journal, 22(2), 161-176. https://doi.org/10.1108/02686900710718663

Quick, R. (2012). EC Green paper proposals and audit quality. Accounting in Europe, 9(1), 17-38. https://doi.org/10.1080/17449480.2012.664398 


\section{MInstitute Macrothink $_{\text {Int }}$}

International Journal of Accounting and Financial Reporting ISSN 2162-3082

Ratzinger-Sakel, N. V., Audousset-coulier, S., Kettunen, J., \& Lesage, C. (2013). Joint audit issues and challenges for researchers and policy-makers. Accounting in Europe, 10(2), 175-199. https://doi.org/10.1080/17449480.2013.834725

Roychowdhury, S. (2006). Earnings management through real activities manipulation. Journal of Accounting and Economics, 42, 335-370. https://doi.org/10.1016/j.jacceco.2006.01.002

Rusmin, R. (2010). Auditor quality and earnings management: Singaporean evidence. Managerial Auditing Journal, 25(7), 618-638. https://doi.org/10.1108/02686901011061324

Rutledge, R. W., Karim, K. E. \& Luo, X. (2014). The Effects of SOX on Firms Audited by Big-4 versus Non-Big-4 audit firms. Journal of Accounting and Finance, 14(1), 86-102.

Schipper, K. (1989). Earnings management. Accounting Horizons, 3(4), 91-102.

Shuang, X., Xiang, C., \& Hong, G. (2010). Are cash flows managed?: Empirical evidence from quarterly financial statements of listed Chinese firms. Retrieved June 11, 2016, from http://www.sinoss.net/qikan/uploadfile/2010/1130/8946.pdf

Sikka, P. (2009). Financial crisis and the silence of the auditors. Accounting, Organizations and Society, 34(6-7), 868-873. https://doi.org/10.1016/j.aos.2009.01.004

Siregar, S. V., \& Utama, S. (2008). Type of earnings management and the effect of ownership structure, firm size, and corporate-governance practices: Evidence from Indonesia. The International Journal of Accounting, 43, 1-27. https://doi.org/10.1016/j.intacc.2008.01.001

Velte, P., \& Azibi, J. (2015). Are joint audits a proper instrument for increased audit quality. British Journal of Applied Science and Technology, 7(6), 528-551. https://doi.org/10.9734/BJAST/2015/15599

Watts, R., \& Zimmerman, J. (1990). Positive Accounting Theory: A ten year perspective. The Accounting Review, 65, 131-156.

Yaping, N. (2005). The theoretical framework of earnings management. Canadian Social Science, 1(3), 32-38.

Yaşar, A. (2013). Big Four Auditors, Audit Quality and Earnings Management: Evidence from Turkish Stock Market. International Journal of Business and Social Science, 4(17), 153-163.

Zang, A. Z. (2012). Evidence on the trade-off between real activities manipulation and accrual-based earnings management. The Accounting Review, 87(2), 675-703. https://doi.org/10.2308/accr-10196

Zerni, M., Kallunki, J., \& Nilsson, H. (2010). The entrenchment problem, corporate governance mechanisms, and firm value. Contemporary Accounting Research, 27(4), 1169-1206. https://doi.org/10.1111/j.1911-3846.2010.01043.x

Zerni, M., Haapamaki, E., Jarvinen, T., \& Niemi, I. (2012). Do joint audits improve audit 


\section{Macrothink \\ International Journal of Accounting and Financial Reporting \\ ISSN 2162-3082 \\ 2018, Vol. 8, No. 1}

quality? Evidence from voluntary joint audits. European Accounting Review, 21(4), 731-765. https://doi.org/10.1080/09638180.2012.678599

Zhang, R. (2006). Cash flow management, incentives, and market pricing. https://doi.org/10.2139/ssrn.817324

Zhang, R. (2009). Cash flow management in the Chinese stock market: An empirical assessment with comparison to the U.S. market. Frontiers of Business Research in China, 3(2), 301-322. https://doi.org/10.1007/s11782-009-0015-1

Zhu, T., Lu, M., Shan, Y., \& Zhang, Y. (2015).Accrual-based and real activity earnings management at the back door: Evidence from Chinese reverse. Pacific-Basin Finance Journal, 35, 317-339. https://doi.org/10.1016/j.pacfin.2015.01.008

\section{Copyright Disclaimer}

Copyright for this article is retained by the author(s), with first publication rights granted to the journal.

This is an open-access article distributed under the terms and conditions of the Creative Commons Attribution license (http://creativecommons.org/licenses/by/3.0/). 